UDK 327:620.9(4-672EU)

Biblid 0543-3657, 71 (2020)

God. LXXI, br. 1179-80, str. 119-138

izvorni naučni rad

Primljen: 13.5.2020.

doi: https://doi.org/10.18485/iipe_mp.2020.71.1179_80.6

Nevena ŠEKARIĆ ${ }^{1}$

\title{
Evropska energetska bezbednost: slučaj Severnog toka 2
}

\author{
SAŽETAK
}

U domenu evropske energetske bezbednosti poslednjih nekoliko godina velika pažnja se posvećuje naporima Evropske unije ka uspostavljanju integrisane energetske politike i jačanju Energetske unije. Posledično, mnogi izazovi koji stoje na tom putu takođe su predmet brojnih analiza. Jedan od najznačajnijih savremenih izazova sa kojima se suočava evropska energetska integracija jeste projekat Severni tok 2, čija realizacija dovodi do uvećanja evropske energetske zavisnosti od ruskog prirodnog gasa. Osnovni cilj ovog rada jeste analiza skorašnjih trendova i uticaja koji stoje u vezi sa ovim gasovodom, odnosno procena njegovog uticaja na dalje integrativne korake Evropske unije $u$ oblasti energetske bezbednosti. $S$ obzirom na izraženu regionalnu dimenziju ovog projekata, ključni teorijski okvir koji će omogućiti takvu analizu jeste Teorija regionalnog bezbednosnog kompleksa, originalno razvijena od strane Kopenhaške škole studija bezbednosti.

Ključne reči: Evropska unija, energetska bezbednost, energetska politika, Teorija regionalnog bezbednosnog kompleksa, prirodni gas, Severni tok 2, gasovodi.

\section{Uvod}

Sa značajem koji prirodni gas danas ima po energetsku bezbednost mnogih aktera $u$ međunarodnoj zajednici, pitanje (novih) gasovoda postaje sve

\footnotetext{
${ }^{1}$ Autorka je istraživač-pripravnik u Institutu za međunarodnu politiku i privredu, Beograd, e-mail: nevena.sekaric@diplomacy.bg.ac.rs

Rad je nastao u okviru naučnoistraživačkog projekta „Srbija i izazovi u međunarodnim odnosima 2020. godine“, koji finansira Ministarstvo prosvete, nauke i tehnološkog razvoja Republike Srbije, a realizuje Institut za međunarodnu politiku i privredu tokom 2020. godine.
} 
aktuelnije i privlači sve više pažnje teoretičara međunarodnih odnosa, ali i donosilaca političkih odluka. U kontekstu evropske energetske bezbednosti, projekat Severni tok 2 predstavlja jedno od takvih najkontroverznijih pitanja. Severni tok 2, budući da označava projekat kojim bi se dodatni ruski prirodni gas direktno dopremao na nemačku teritoriju, predmet je mnogih debata, kako onih akademskih tako i dnevnopolitičkih. ${ }^{2}$ Kao što se često navodi, ovaj gasovod podelio je Evropsku uniju (EU) na dve strane - na one koji podržavaju realizaciju ovog projekta (oličene $u$ vidu gasnih kompanija iz Nemačke, Francuske i Austrije) i oštre oponente dodatnom povećanju evropske energetske zavisnosti od ruskog prirodnog gasa (uglavnom predvođene centralnim $\mathrm{i}$ istočnoevropskim državama). ${ }^{3}$ Osim toga, pored snažne političke i bezbednosne konotacije, projektu Severni tok 2 pripisuje se i neusklađenost sa postojećom regulativom EU u oblasti energetske bezbednosti i novim strategijama kojima se diverzifikacija energetskih izvora smatra prioritetnom. ${ }^{4}$ Neki idu dotle da ovaj projekat označavaju kao ruski izgovor za proširenje sopstvenog prisustva na baltičkoj teritoriji, odnosno, kao političko oružje koje Rusija koristi u svom spoljnopolitičkom nastupu. ${ }^{5} \mathrm{U}$ tom smislu, nisu retki pokušaji u sekuritizaciji ovog pitanja, označavajući ga upravo bezbednosnom pretnjom po sveukupnu energetsku bezbednost Evropske unije. ${ }^{6}$

Ukupni kapacitet Severnog toka 2 (dužine 1.200 km) iznosi 55 milijardi kubnih metara gasa godišnje, dok celokupna vrednost projekta iznosi skoro 10 milijardi evra. S obzirom na to da agregatni kapacitet Severnog toka $1 \mathrm{i}$ Severnog toka 2 iznosi 110 milijardi kubnih metara gasa na godišnjem nivou, ovim projektom isporuka ruskog prirodnog gasa $u$ Evropu se praktično

${ }^{2}$ Primera radi, pedeset eksperata za bezbednost iz osamnaest država članica EU javno je apelovalo navodeći šest glavnih razloga zašto bi Severni tok 2 predstavljao stratešku grešku Nemačke u budućem periodu (European Values Center for Security Policy, Public Appeal of security experts from EU member states: 6 reasons Nord Stream 2 will be Germany's strategic mistake for decades to come, Prague, 2018, Internet, https:// www.europeanvalues.net/nordstream/,1/4/2020).

${ }^{3}$ Agata Loskot-Strachota, Nord Stream 2: policy dilemmas and the future of EU gas market, Norwegian Institute of International Affairs, Oslo, 2016, Internet, https:// www.europeangashub.com/wp-content/uploads/attach_580.pdf, 1/4/2020, p. 1.

${ }^{4}$ Severin Fischer, "Nord Stream 2: Trust in Europe", Policy Perspectives, vol. 4, no. 4, March 2016, pp. 1-4.

${ }^{5}$ Mychajło Honczar, Nord Stream 2 is not just a business. The Baltic is becoming a place of confrontation with NATO, Gazeta Prawna, Warsaw, 2019, Internet, https://serwisy. gazetaprawna.pl/energetyka/artykuly/1422553,nord-stream-2-nato-obwodkaliningradzki.html, 1/4/2020.

${ }^{6}$ Poljski državni sekretar za evropske poslove nazvao ga je "Trojanskim konjem“ sposobnim da "destabilizuje ekonomiju i otruje političke odnose u EU“ (Jan Jančík, Nord Stream 2: In accordance with the EU's Energy security strategy?, Faculty of Social Sciences,

120 Prague, 2019, p. 38). 
udvostručuje. ${ }^{7}$ Poređenja radi, kapacitet ukrajinske rute iznosi 142 milijarde kubnih metara gasa godišnje. Izgradnja drugog baltičkog gasovoda, kojim se ruski prirodni gas transportuje direktno u Nemačku preko Baltičkog mora, zaobilazi države nečlanice EU, poput Belorusije i Ukrajine, što ima snažan politički i bezbednosni predznak, naročito kada se uzme u obzir istorija gasnih poremećaja tokom 2005/06, 2009. i 2014. godine i zaoštreni (energetski) odnosi na relaciji Rusija-Ukrajina. Izostavljanje Ukrajine iz ove energetske jednačine dodatno je naglašeno najavom Rusije da će prestati sa isporukom prirodnog gasa evropskim zemljama putem tradicionalne ukrajinske gasne rute koja se pokazala „nepouzdanom“.$^{8}$ Osim direktne zabrinutosti većine članica EU povodom ovog gasovoda, Severni tok 2 podigao je i međunarodnu pozornost gde najeklatantniji primer predstavlja uvođenje sankcija od strane Sjedinjenih Američkih Država kompanijama koje pomažu ruskom Gazpromu u realizaciji ovog projekta. ${ }^{9}$ Iako je njegovo finalno puštanje najavljivano za početak 2020. godine, budućnost ovog gasovoda je za sada neizvesna, a neke od skorijih vesti ukazuju na takvo odlaganje za prvi kvartal 2021. godine, usled brojnih birokratskih prepreka i oštre debate na evropskom prostoru. ${ }^{10}$

Kako su napori Evropske unije ka uspostavljanju integrisane energetske politike i Energetske unije naročito postali vidljivi nakon Ukrajinske krize iz 2014. godine, Severni tok 2 se očigledno nameće kao prepreka takvoj integraciji

${ }^{7}$ Gazprom, Nord Stream 2, Moscow, 2019, https:// www.gazprom.com/ projects/nordstream2/, 2/4/2020. Dok Gazprom finansira polovinu projekta Severni tok 2, ostatak finansiranja obavlja pet evropskih kompanija: francuski ENGIE, austrijski OMV, britansko-holandski Royal Dutch Shell, nemački Uniper i nemački Wintershall.

${ }^{8}$ Iako su postojale bojazni da bi ruski gas zaista mogao prestati da se transportuje putem ukrajinske rute (po isteku desetogodišnjeg ugovora), krajem 2019. godine Rusija i Ukrajina su postigle "principijelni sporazum" o nastavku ovog tranzita do 2024. godine (Deutsche Welle, Russia and Ukraine agree to gas transit deal, Berlin, 2019, Internet, https:// www.dw.com/en/russia-and-ukraine-agree-to-gas-transit-deal/a-51743639, 1/4/2020).

${ }^{9}$ Zakon kojim se predviđaju pomenute sankcije podrazumeva zamrzavanje imovine i ukidanje američkih viza za preduzetnike koji se bave Severnim tokom 2 (Danas, Tramp potpisao zakon koji sadrži sankcije za gasovod Severni tok dva, Beograd, 2019, Internet, https://www.danas.rs/svet/tramp-potpisao-zakon-koji-sadrzi-sankcije-za-gasovodseverni-tok-dva/, 2/4/2020). Tramp je potpisao ovaj zakon krajem 2019. godine, navodeći tom prilikom da Severni tok 2 predstavlja "sredstvo političke prinude“, pri čemu bi realizacija ovog projekta istovremeno značila i smanjenje isporuka američkog tečnog prirodnog gasa (LNG) Evropi (Deutsche Welle, Germany, EU decry US Nord Stream sanctions, Berlin, 2019, Internet, https:/ / www.dw.com/en/germany-eu-decryus-nord-stream-sanctions/a-51759319, 2/4/2020).

${ }^{10}$ Stuart Elliott \& Rosemary Griffin, Nord Stream 2 gas pipeline could be delayed to Q1 2021: Putin, S\&P Global Platts, January 2020, Internet, https://www.spglobal.com/ platts/en/market-insights/ latest-news/natural-gas/011320-nord-stream-2-gaspipeline-could-be-delayed-to-q1-2021-putin, 17/4/2020. 
budući da je podelio EU po pitanju budućnosti njene energetske bezbednosti. I dok za Rusiju Severni tok 2 predstavlja projekat nacionalnog značaja, zapadnoevropske gasne kompanije imaju značajne komercijalne razloge zbog kojih podržavaju finalizaciju ovog projekta. ${ }^{11}$ Iako treba uvažiti nacionalne i komercijalne interese strana uključenih u realizaciju ovog projekta, nemoguće je posmatrati ih razložno od geopolitičkih implikacija koje on može imati po sveukupnost odnosa između EU i Ruske Federacije. Budući da je predmet tematizovanja ovog rada evropska perspektiva, glavna pitanja na koja treba dati odgovor jesu na koji način Severni tok 2 utiče na Evropsku uniju, odnosno, kakve su implikacije njegove realizacije po unutrašnju i spoljnu dinamiku kompleksa centriranog oko EU u domenu energetske politike. Analiza ovog slučaja podrazumeva posmatranje predmeta istraživanja kroz prizmu Teorije regionalnog bezbednosnog kompleksa (TRBK), gde su istraživački ciljevi deskripcija i eksplikacija načina na koji Severni tok 2 može uticati na odnose između jedinica proučavanog kompleksa, kao i na odnose koji se uspostavljaju u međuregionalnim okvirima.

\section{Energetska bezbednost: evropska perspektiva}

Gotovo je opštepoznato da je proširivanje i produbljivanje studija bezbednosti u posthladnoratovskom periodu utrlo put promeni perspektive povodom onoga šta se smatra pretnjom. Ovakvo preispitivanje prirode pretnji okarakterisalo je kako akademsku, tako i dnevnopolitičku debatu, posebno na evropskom prostoru. Za razliku od prethodne Evropske bezbednosne strategije gde energetska pitanja nisu bila tretirana, energetska nebezbednost je u Globalnoj strategiji Evropske unije, pored drugih, uvrštena $\mathrm{u}$ red pretnji koje narušavaju sveukupnu bezbednost EU. ${ }^{12}$ I dok postoje brojna određenja energetske bezbednosti, u zavisnosti od ugla iz kog se ovaj koncept posmatra, energetska bezbednost za Evropsku uniju predstavlja ne samo bezbednosno pitanje, već i stvar strateškog i istorijskog značaja. ${ }^{13}$

Multidimenzionalna priroda energetske bezbednosti uslovila je i brojne pokušaje njenog određenja. Osim toga, česti su i pokušaji definisanja najoptimalnijeg modela i pripadajućih dimenzija i kriterijuma koje treba

11 "Energy Strategy of Russia for the Period up to 2030", Ministry of Energy of the Russian Federation, Moscow, 2010, p. 81.

12 "Shared Vision: Common Action: A Stronger Europe. A Global Strategy for the European Union's Foreign and Security Policy", European Union, 2016, pp. 9, 18-19.

${ }^{13}$ Ovde se prvenstveno misli na početne integrativne korake u stvaranju Evropske zajednice (preteče EU) čija su dva od tri stuba bila povezana sa ključnim energentima toga doba (Vladimir Trapara i Nevena Šekarić, „Saradnja kao (ne)očekivan efekat energetske bezbednosne dileme: studija slučaja Bugarske, Grčke i Jugoslavije“,

122 Međunarodni problemi, vol. LXXI, no. 2, pp. 215-243). 
koristiti u analizi energetske bezbednosti jedne države. I dok obim ovog rada ne dozvoljava detaljnije elaboriranje takvih definicija, važno je istaći da uloga konkretne države na energetskom tržištu (da li je u pitanju država izvoznica, tranzitna, ili pak država uvoznica energenata) diktira i sam način na koji se posmatra energetska bezbednost. S obzirom na to da danas Evropska unija predstavlja jednog od najvećeg potrošača prirodnog gasa, jasno je da se, iz evropske perspektive, energetska bezbednost primarno posmatra kao bezbednost snabdevanja. ${ }^{14}$ Osim toga, energetska bezbednost (naročito $u$ kontekstu EU) može se postići implementacijom različitih mera, poput diverzifikacije energetskih izvora i dobavljača, razvoja strateških rezervi energije, izgradnje redundantne infrastrukture, kao i izgradnjom interkonektora između država članica koje imaju mogućnosti obrnutog protoka. ${ }^{15}$ Nekada primarno pitanje inženjerske struke, danas su energetske strategije predmet interesovanja mnogih drugih aktera i značajan alat $u$ ostvarivanju (geo)političkih interesa. Dodatno, spoljnopolitički energetski nastup EU (kao i drugih velikih i regionalnih sila ili regionalnih organizacija) prilagođen je interesima koji direktno proističu iz pokušaja osiguravanja sopstvene energetske bezbednosti. ${ }^{16}$

Ključni energenti i putevi njihovog saobraćanja su oduvek bili predmet političkih sporenja i, neretko, konflikata, pri čemu je jedno od najznačajnijih pitanja postalo upravo pitanje bezbednosti snabdevanja (odnosno, bezbednost potražnje za države izvoznice energenata). Danas se energetska bezbednost dovodi i u vrlo blisku vezu sa klimatskim promenama i iznalaženjem novih, alternativnih energetskih izvora s obzirom na sve glasnije zagovaranje dekarbonizacije u proizvodnji i potrošnji energije. S tim $\mathrm{u}$ vezi, savremena evropska energetska agenda prepoznala je značaj svih ovih pitanja i učinila energetsku bezbednost jednim od svojih ključnih prioriteta tokom poslednjih decenija XXI veka.

$S$ obzirom na to da potrošnja prirodnog gasa u Evropskoj uniji znatno prevazilazi njegovu proizvodnju u domaćim okvirima, EU je primorana da veliki deo ovog energenta uvozi od eksternih proizvođača. ${ }^{17}$ Osim neznatnog uvoza prirodnog gasa u EU iz Norveške, Alžira i Katara, Rusija definitivno

${ }^{14}$ Uglavnom se, $\mathrm{u}$ ovom kontekstu, koristi definicija data od strane Međunarodne agencije za energetiku, prema kojoj energetska bezbednost predstavlja kontinuirani pristup energetskim resursima po pristupačnoj ceni.

${ }^{15}$ Callie Le Renard, External Actors and National Preference Formation: European Energy Security Policy E Relations with Russia, George Mason University, Fairfax, 2013, pp. 10-11.

${ }^{16}$ Dušan Proroković, "Geopolitički kontekst energetske bezbednosti“, Međunarodni problemi, vol. LXXII, no. 1, 2020, str. 270.

${ }^{17}$ Prema zvaničnim podacima, tokom 2018. godine cela Evropa je proizvela 250,7 bcm gasa, dok je potrošnja za isti period iznosila dvostruko više $-549 \mathrm{bcm}$ prirodnog gasa ("BP Statistical Review of World Energy", British Petroleum, June 2019, pp. 32, 34). 
predstavlja primarnog snabdevača Evropske unije prirodnim gasom. Tokom 2017. i 2018. godine, Rusija je EU snabdevala gasom u iznosu od 39,3\%, odnosno, $40,2 \%$, a predikcije $u$ vezi sa uvozom ovog energenta govore $u$ prilog povećanju takve aktivnosti u bliskoj budućnosti. ${ }^{18}$ Pomenuto naročito dobija na značaju kada se ima u vidu da su istočnoevropske zemlje gotovo $100 \%$ zavisne od uvoza ruskog prirodnog gasa, gde bi potpuni prekid njegove isporuke imao značajne posledice po energetsku bezbednost ovih država. ${ }^{19}$ Ovakva rastuća evropska energetska zavisnost od Rusije, ali i serija gasnih kriza tokom poslednjih petnaest godina između ova dva aktera, rezultirale su usvajanjem novih pogleda i strategija Evropske unije u oblasti energetske bezbednosti, primarno usmerenih ka diverzifikaciji izvora i puteva snabdevanja ključnih energenata, pored sve većeg oslanjanja na obnovljive izvore energije. ${ }^{20}$ Pored diverzifikacije, ideja o tzv. Energetskoj uniji naglo je postala eksploatisana tokom 2015. godine; bojazni koje su okarakterisale Ukrajinsku krizu iz 2014. godine, uvođenje sankcija Rusiji, kao i nemiri na Bliskom istoku usled "arapskog proleća“, učinili su pitanja bezbednosti snabdevanja EU prioritetnim. Svi ovi faktori doprineli su snažnijem zalaganju EU za integraciju evropske energetske politike i zagovaranju jedinstvenog spoljnopolitičkog energetskog nastupa.

\section{Teorija regionalnog bezbednosnog kompleksa: analiza slučaja Severni tok 2}

Kopenhaška škola studija bezbednosti (u daljem tekstu: Kopenhaška škola) na jedinstven način sintetiše ključne realističke i konstruktivističke alate $\mathrm{u}$ promišljanju bezbednosnih pitanja. Glavni teorijski doprinosi ove škole ogledaju se $u$ teoriji sekuritizacije, sektorskom pristupu i teoriji regionalnog bezbednosnog kompleksa. Zainteresovanost za regionalni nivo bezbednosti, koji akcentuje Kopenhaška škola, izvire iz činjenice da su regioni po okončanju Hladnog rata dobili značajno mesto $u$ analizi bezbednosnih pojava i relacija, odnosno da je takav obrazac međunarodnih odnosa radikalno drugačiji od krute bipolarne strukture koja je okarakterisala hladnoratovski period, što je opravdalo potrebu za razvijanjem teorijskih i konceptualnih okvira prilagođenih analizi te ",nove“ forme bezbednosnih odnosa i bezbednosne dinamike. ${ }^{21}$ Prema mišljenju

18 "EU imports of energy products - recent developments", Eurostat, May 2019, p. 4.

19 "EU imports of energy products - recent developments", Eurostat, November 2019, pp. 9-10.

${ }^{20}$ Primera radi, projekat koji ispunjava načela Energetske unije u vezi sa diverzifikacijom snabdevača i ruta snabdevanja jeste Južni gasni koridor kojim se azerbejdžanski gas doprema na evropsku teritoriju preko Turske.

${ }^{21}$ Barry Buzan \& Ole Wæver, Regions and powers: the structure of international security,

124 Cambridge University Press, Cambridge, 2003, pp. 3-4. 
predstavnika Kopenhaške škole, Buzena i Vejvera (Barry Buzan \& Ole Wrver), za proučavanje bezbednosti ključna je unutrašnja regionalna dinamika, tj. ona koja se uspostavlja unutar jednog regionalnog kompleksa, između jedinica/država tog kompleksa. Drugim rečima, jedan regionalni bezbednosni kompleks (RBK) čini set jedinica čiji su glavni procesi (de)sekuritizacije toliko međusobno povezani da se njihovi bezbednosni problemi ne mogu analizirati niti rešavati odvojeno. ${ }^{22} \mathrm{Uz}$ tvrdnju da je bezbednost ono što akteri naprave od nje, značaj sekuritizujućeg poteza za nastanak i funkcionisanje jednog RBK je i više nego očigledan, a upravo politički diskurs koji koriste sekuritizujući akteri materijalizuje bezbednosnu pretnju, odnosno, prepoznaje i izdvaja ono što ugrožava jedinice/države tog kompleksa. RBK jeste prvenstveno analitički koncept; regionalni bezbednosni kompleksi su socijalno konstruisani i kao takvi određeni stvarnim bezbednosnim praksama njihovih glavnih aktera. ${ }^{23}$ TRBK, stoga, pruža adekvatan analitički okvir za tematizovanje onih pitanja koja imaju snažni regionalni bezbednosni predznak (poput samih gasovoda) te utiču na odnose koji se uspostavljaju između jedinica (država) unutar jednog RBK, kao i na regionalnu dinamiku. Na taj način, teorija predstavlja dobru osnovu za analizu unutrašnje dinamike EU u domenu energetske bezbednosti (sa akcentom na prirodni gas $\mathrm{u}$ konkretnom slučaju) i međuregionalnih odnosa koji se uspostavljaju između EU i Rusije, odnosno, kompleksa centriranih oko ova dva aktera. ${ }^{24}$

Iako predstavnici Kopenhaške škole regionalne bezbednosne komplekse vide pre kao dugotrajne obrasce prijateljstva i neprijateljstva (budući da ih primarno tvore države kao fiksni elementi) negoli promenljive, ne treba odreći mogućnost njihove transformacije $u$ određenom vremenskom periodu. Kako to navodi Lipovac, „,... region predstavlja i dovoljno dinamičan okvir koji ostavlja mogućnost za transformacije ovih (regionalnih, prim. aut.) karakteristika u pojedinim delovima, ali i implikaciju ovih promena kroz regionalnu bezbednosnu dinamiku i odnose između država unutar regiona“ ${ }^{25}$ Drugim rečima, promena bezbednosne međuzavisnosti u odnosima između

${ }^{22}$ Ibid., p. 44.

${ }^{23}$ Ibid., p. 48.

${ }^{24} \mathrm{U}$ kontekstu ove teorije, treba napomenuti da Evropu danas čine dva regionalna bezbednosna kompleksa sa dve velike sile: kompleks centriran oko EU (koji je ujedno i predmet tematizovanja ovog rada) i kompleks centriran oko Rusije. S obzirom na geografsku blizinu ova dva kompleksa, oni danas formiraju labavi superkompleks, ali ih nedovoljna uključenost $u$ međusobna bezbednosna pitanja sprečava $u$ formiranju jedinstvenog kompleksa (Ibid., p. 343). Svakako, pomenuto je pod znakom pitanja ukoliko se posmatra isključivo međusobna uključenost ovih kompleksa povodom ključnih energetskih pitanja.

${ }^{25}$ Milan Lipovac, Nacionalna bezbednost Republike Srbije u regionalnom bezbednosnom potkompleksu Zapadni Balkan, Fakultet bezbednosti, Beograd, 2016, str. 98. 
jedinica (država) jednog kompleksa ili takva promena u međuregionalnim okvirima može biti jedan od faktora transformacije. Preneto na kontekst ove konkretne studije, promene $u$ obrascima energetske (među)zavisnosti mogu imati pokretačku ulogu u transformaciji određenih karakteristika kompleksa. Još konkretnije, sa realizacijom gasovoda Severni tok 2, kojim se isporuka ruskog prirodnog gasa EU gotovo udvostručuje u poređenju sa kapacitetom Severnog toka 1, evropska energetska zavisnost od Rusije se znatno uvećava, te je uputno preispitati unutrašnju strukturu samog kompleksa, njegove moguće transformacije $\mathrm{u}$ budućem periodu i postojeće međuregionalne bezbednosne obrasce. ${ }^{26}$

Pored deskriptivnog momenta koji omogućava opštu tipologiju formi koje jedan regionalni bezbednosni kompleks može poprimiti, teorija se odlikuje i prediktivnim elementom koji predstavlja osnovu za procenu manje ili više verovatnih promena koje taj RBK može doživeti na osnovu različitih faktora. ${ }^{27}$ U pogledu opšte tipologije formi, raznovrsni geografski, politički, istorijski, ekonomski i/ili kulturološki faktori određuju jedan bezbednosni kompleks do te mere da on per se predstavlja centar svih bezbednosnih briga. ${ }^{28} \mathrm{U}$ vezi s tim, najpre je neophodno odrediti koji su to faktori koji su oblikovali tip kompleksa centriranog oko EU u pogledu predmeta istraživanja - Severnog toka 2 i njegovog uticaja na evropsku energetsku bezbednost. Opis trenutnog stanja kompleksa povodom ovog konkretnog pitanja omogućiće potom i analizu potencijalnih scenarija kretanja kompleksa u narednom periodu.

Kako bi se dobio odgovor na pitanje na koji način Severni tok 2 utiče na unutrašnju i spoljnu dinamiku kompleksa centriranog oko EU u domenu energetske bezbednosti, potrebno je, shodno smernicama koje nudi TRBK, analizu sprovesti identifikovanjem nekoliko bitnih faktora. ${ }^{29}$ Prvi korak podrazumeva sticanje uvida $u$ istorijat energetskih odnosa između Evropske unije i Rusije gde je od primarne važnosti definisati primarne eksplanatorne faktore koji su doprineli sekuritizovanju energetskih pitanja i, što je najvažnije za ovo istraživanje, sekuritizovanju Severnog toka 2. Zatim, identifikacija glavnih aktera u kompleksu centriranom oko EU i unutrašnje dinamike koja je doprinela sekuritizovanju ovog pitanja omogućiće i definisanje tipa

${ }^{26}$ Ovome naročito doprinosi i mogućnost izgradnje tzv. Turskog toka, još jednog ruskog gasovoda kojim bi se prirodni gas dopremao južnom delu evropske teritorije (slično nekadašnjem projektu Južni tok).

${ }^{27}$ Barry Buzan \& Ole Wæver, Regions and powers: the structure of international security, op. cit., p. 86.

${ }^{28}$ Barry Buzan, People, states, and fear: The national security problem in international relations, Wheatsheaf Books, Brighton, 1983, p. 106.

${ }^{29}$ Analiza je metodološki sprovedena slično načinu na koji je to učinjeno u: Tim Bogaert, Rock the Pipeline: A Strategic Analysis of the Nord Stream 2 Conundrum, Vrije Universiteit

126 Brussel, Brussel, 2019, pp. 1-49. 
bezbednosnog kompleksa u kontekstu konkretnog predmeta istraživanja i kriterijuma centralizacije moći, kao i raspoređivanje ključnih aktera RBK na spektru (ne)prijateljstva. ${ }^{30}$ S obzirom da je, prema Buzenu i Vejveru, struktura jednog RBK u najvećoj meri određena upravo odnosima moći i obrascima (ne)prijateljstva, to se ovaj korak nameće kao neophodan. ${ }^{31}$ Nakon bavljenja unutrašnjom strukturom kompleksa, neophodno je predmet istraživanja postaviti u međuregionalne okvire, odnosno, pridružiti joj analizu međuregionalne dinamike između kompleksa centriranog oko EU i onog centriranog oko Rusije. Poslednji korak implicira analizu mogućih budućih scenarija RBK na osnovu prethodno sprovedenih istraživačkih koraka. ${ }^{32}$

U pogledu istorije energetskih odnosa između EU i Rusije, može se uočiti postepena politizacija, a potom i sekuritizacija energetskih pitanja. Ukoliko se posmatra sveobuhvatnost njihovih energetskih odnosa u kontekstu prirodnog gasa (koji su uspostavljeni još krajem 60-ih godina XX veka), politizacija i sekuritizacija ovog pitanja dešavaju se tek u poslednjih dvadesetak godina. Primarni eksplanatorni faktori koji su doprineli takvom stanju stvari mogu se tražiti u tzv. novoj formi energetskih odnosa između Evropske unije i Rusije uspostavljanjem Energetskog dijaloga, (ponovnim) jačanjem Rusije početkom XXI veka i njenim oslanjanjem na energetiku u spoljnopolitičkom nastupu, sveopštoj promeni paradigme sa koncepta uzajamne energetske međuzavisnosti na koncept diverzifikacije ruta energenata i, možda najznačajnije, ključnim energetskim događajima koji su obeležili prve dve decenije XXI veka u odnosima između ova dva aktera. ${ }^{33}$ Drugim rečima, tržišno

${ }^{30}$ Četiri ključne varijable koje čine esencijalnu strukturu jednog RBK jesu: granice (koje razdvajaju više RBK), anarhična struktura (koja podrazumeva da se RBK mora sastojati iz najmanje dve autonomne jedinice), polaritet (posledica odnosa moći jedinica RBK) i socijalna konstrukcija (podrazumeva obrasce prijateljstva i neprijateljstva između jedinica RBK) (Barry Buzan \& Ole Wæver, Regions and powers: the structure of international security, op. cit., p. 53). Unutar navedenih parametara, moguće je razlikovati i različite tipove RBK: prema polaritetu se razlikuju unipolarni, bipolarni, tripolarni i multipolarni RBK; prema centralizaciji moći razlikujemo standardne i centrirane RBK; prema obrascima (ne)prijateljstva pravimo razliku između konfliktnih formacija, bezbednosnih režima i bezbednosnih zajednica (Ibid., pp. 53-57).

${ }^{31}$ Ibid., p. 49.

${ }^{32}$ Scenariji se kreću od održavanja statusa quo, preko unutrašnje do spoljne transformacije regionalnog bezbednosnog kompleksa, o čemu će više reči biti u narednom delu teksta.

${ }^{33}$ Ovde se primarno misli na seriju tzv. gasnih kriza koje su obeležile energetske odnose između EU i Rusije tokom zima 2005/2006. i 2009. godine, kao i na rusku aneksiju Krima tokom 2014. godine. Svaki od ovih događaja bio je praćen donošenjem i usvajanjem odgovarajućih strateških i obavezujućih akata u domenu evropskog energetskog acquis communautaire. Više o pregledu sekundarne legislative EU u domenu energetske politike može se videti u: "Overview of the secondary EU legislation that falls under the legislative competence of DG ENER and that is currently in force", European Commission, 19 December 2014, pp. 1-24. 
orijentisan pristup Evropske unije u rešavanju energetskih pitanja postepeno je zamenjen pristupom sa snažnim (geo)političkim predznakom. ${ }^{34} \mathrm{Na}$ taj način je energetska zavisnost EU od jednog snabdevača postala sekuritizovano pitanje koje je svoj pravni i institucionalni okvir dobilo usvajanjem mnogih regulatornih mehanizama i inicijativa, počev od uspostavljanja Energetske zajednice (2006), usvajanja Zelenog papira (Green paper - A European Strategy for Sustainable, Competitive and Secure Energy) iz 2006. godine i komunikacija Komisije iz 2008. i 2009. godine, preko Trećeg energetskog paketa (2009) i Evropske strategije energetske bezbednosti (2014), do uspostavljanja Energetske unije (2015). ${ }^{35}$ Treći energetski paket koji predstavlja osnovu današnje evropske energetske strategije, zabranjuje da snabdevač prirodnog gasa istovremeno bude i vlasnik gasovoda, dok klauzula o tzv. „trećem pristupu“ obavezuje dobavljača da konkurentima omogući pristup gasovodu, što je, uostalom, bio glavni argument za suspenziju projekta Južni tok. ${ }^{36}$

Evropska strategija energetske bezbednosti iz 2014. godine imala je naročito naglašen geopolitički karakter ističući, među osam ključnih akcija, i značaj dalje integracije evropskog energetskog nastupa i koordinacije nacionalnih energetskih politika, kao i diverzifikacije izvora snabdevanja gasom. ${ }^{37}$ Uspostavljanje Energetske unije kao šireg okvira za ostvarivanje energetske bezbednosti EU još jednom je eksplicitno istaklo poruku kojom se (pored još tri dimenzije) diverzifikacija energetskih izvora $\mathrm{i}$ integrisano unutrašnje energetsko tržište smatraju prioritetima. ${ }^{38}$ Posledično, tokom 2016. godine, došlo je do usvajanja Paketa za bezbednost snabdevanja (Security of Supply Package), revidiranja Uredbe o bezbednosti snabdevanja gasom iz 2010. godine (Security of Gas Supply Regulation), većim mogućnostima Evropske komisije $\mathrm{u}$ ispitivanju međuvladinih sporazuma između EU i trećih dobavljača, kao i utvrđivanja Strategije za tečni prirodni gas. ${ }^{39}$

${ }^{34}$ Anna Avlichou, European Energy Union: Continuity or Change?, Universiteit Leiden, Leiden, 2017, p. 11.

${ }^{35}$ Nevena Šekarić, „Sekuritizacija energetskih odnosa između Evropske unije i Rusije: evropska perspektiva“, Međunarodna politika, vol. LXX, no. 1176, pp. 63-82.

${ }^{36}$ Daniela Munteanu \& Ciro Sarno, "South Stream and Nord Stream 2 - Implications for the European Energy Security", Analise Europeia, vol. 2, no. 1, 2016, p. 65.

37 "European Energy Security Strategy", COM(2014) 330 final, European Commission, 28 May 2014, p. 3. I dok koordinacija nacionalnih energetskih politika uvažava individualnu (nacionalnu) nadležnost za odlučivanje o udelu određenog resursa u energetskom sektoru konkretne države, akcentovan je značaj koordinacije bitnih političkih odluka u domenu evropske energetske bezbednosti i potrebu za daljim integrativnim koracima u tom smeru.

38 "Energy Union package", COM(2015) 80 final, European Commission, 25 February 2015, p. 4.

${ }^{39}$ Andreas Goldthau, Assessing Nord Stream 2: regulation, geopolitics E energy security in the EU, Central Eastern Europe \& the UK, Department of War Studies \& King's Russia

128 Institute, London, 2016, p. 9. 
Revidirana Uredba danas služi kao osnova za realizaciju strateških prioriteta Energetske unije, a ključni mehanizmi kojima se to omogućava jesu regionalna saradnja, princip solidarnosti, veća transparentnost i razmena informacija sa Evropskom komisijom po pitanju bezbednosti snabdevanja, kao i akcenat na Energetskoj zajednici i njenoj bliskoj saradnji sa Evropskom komisijom. ${ }^{40}$ Sam projekat Severni tok 2 rezultirao je i jednim ad hoc instrumentom - izmenom Direktive o gasu iz 2009. godine. Konkretnije, na predlog Evropske komisije iz 2017. godine, EU je nakon pregovora, koji su trajali više od godinu dana, postigla dogovor o izmeni ove Direktive kako bi se primenila na gasovode trećih zemalja, odnosno Severni tok 2 koji, kao priobalni gasovod, $\mathrm{u}$ jednom trenutku ulazi na teritoriju članice EU te podleže evropskim zakonima u oblasti energetske bezbednosti. ${ }^{41}$

Identifikacija ključnih aktera, unutrašnjih procesa i opis trenutnog stanja povodom Severnog toka 2 još jedan je od glavnih metodoloških koraka u rasvetljavanju dinamike na polju evropske energetske bezbednosti u vezi sa ovim projektom. S obzirom na teritorijalno prostiranje Severnog toka 2 i uključene strane, postoji više aktera zainteresovanih za ovaj projekat: najpre, Rusija i zapadnoevropske zemlje čije kompanije učestvuju u njegovoj realizaciji (predvođene Nemačkom), najglasniji su zagovornici završetka projekta. Finska, Švedska i Danska direktno su uključene u postojeću debatu budući da projekat podrazumeva prolazak kroz njihove ekonomske zone i/ili teritorijalne vode. ${ }^{42}$ Sa druge strane, Brisel ulaže sve napore kako bi smanjio evropsku energetsku zavisnost od ruskog prirodnog gasa, a projekat se dodatno suočava i sa oštrim kritikama u pogledu ekoloških kriterijuma. Dalje, planirana ruta zaobilazi centralne i istočnoevropske zemlje koje na taj

${ }^{40}$ Beatriz Sinobas \& Anna Samsel van Haasteren, The Revised Security of Gas Supply Regulation, Central Europe Energy Partners, Brussels, 2016, Internet, https:// www.ceep.be/revised-security-gas-supply-regulation/, 15/4/2020.

${ }^{41}$ Katja Yafimava, Gas Directive amendment: implications for Nord Stream 2, The Oxford Institute for Energy Studies, Oxford, 2019, p. 1. Kritike upućene ovom potezu navode da je ovaj amandman sačinjen tako da svi postojeći gasovodi koji su završeni do datuma stupanja na snagu revidirane Direktive mogu da odstupaju od pravila EU o tržištu gasa, izuzev samog Severnog toka 2 (Georgi Gotev, Nord Stream 2 seeks arbitration in dispute with EU Commission, Euractiv, Brussels, 2019, Internet, https:// www.euractiv.com/section/energy/news/nord-stream-2-seeks-arbitration-indispute-with-eu-commission/,5/5/2020). Budući da je revidirana Direktiva stupila na snagu u julu 2019. godine, a da Severni tok 2 nije završen do tog datuma, jasna je implikacija po sam projekat.

${ }^{42}$ I dok je oštra debata oko Severnog toka 2 generalno zaobišla Finsku, Švedska i Danska zatražile su najpre mišljenje Evropske komisije o projektu pre izdavanja dozvola za nastavak rada (Madalina Sisu Vicari, Nord Stream 2: How A Legal Matter Became Part A Soft Power's Aspect, Vocal Europe, Brussels, June 2017, Internet, https:/ /www.vocal europe.eu/nord-stream-2-legal-matter-became-part-soft-powers-aspect/, 5/5/2020). 
način ostaju bez učešća u tranzitu prirodnog gasa. Ukrajina je dodatno bila zabrinuta povodom najave Gazproma da će prekinuti sa isporukom gasa preko njene teritorije, što bi je, zajedno sa realizacijom Severnog toka 2, ostavilo bez direktnog učešća u tranzitu ovog energenta. Osim Ukrajine, Poljska, Slovačka i Mađarska bi u tom slučaju ostale i bez značajnih tranzitnih taksi koje igraju značajnu ulogu u njihovim državnim budžetima. Sjedinjene Američke Države (kao eksterni akter), usvajanjem sankcija protiv kompanija koje učestvuju u ovom projektu, pokazale su direktnu zainteresovanost koja je dodatno naglašena brigom za isporuku američkog tečnog prirodnog gasa Evropi. ${ }^{43}$ U vezi sa oponentima Severnog toka 2, značajno je pomenuti da se uglavnom istočnoevropske i baltičke države protive realizaciji ovog projekta (što je, uostalom, i očekivano s obzirom na tradicionalni ruski uticaj koji postoji u ovim zemljama). ${ }^{44}$

Kako se dâ primetiti, pitanje Severnog toka 2 okuplja mnoge zainteresovane aktere koji se uglavnom svrstavaju u grupu pristalica i protivnika ovog projekta. Kako određena grupa država favorizuje projekat i tako prednost daje bilateralnim energetskim aranžmanima (na čelu sa Nemačkom koja se već sada naziva evropskim „energetskim čvorištem“), projekat Energetske unije i dalja integracija evropskog energetskog tržišta naišli su na svojevrstan otpor. U vezi s tim, kompleks se kreće negde između tri opcije: ili centrirani institucionalni bezbednosni kompleks gde Evropska komisija igra ključnu ulogu, ili kompleks centriran oko Nemačke, dok poslednja opcija referiše na standardni bezbednosni kompleks gde svaki od aktera donosi sopstvene odluke, bez obzira na integrativne pokušaje na nadnacionalnom nivou. ${ }^{45} \mathrm{~S}$ obzirom na to da je budućnost Severnog toka još uvek neizvesna, izgleda da će definitivna uloga Evropske komisije opredeliti i tip samog kompleksa u pogledu kriterijuma centralizacije moći. ${ }^{46}$

${ }^{43}$ Sankcije SAD Severnom toku 2 primer su uticaja globalne sile na kompleks centriran oko EU. I dok se SAD u konkretnom slučaju ne mogu smatrati prekrivačem (overlay), ipak ne treba prenebregnuti njihovu zainteresovanost za ovo pitanje.

${ }^{44}$ Tokom 2016. godine, Poljska, Mađarska, Slovačka, Češka, Estonija, Letonija, Litvanija i Rumunija uputile su svoje protivljenje predsedniku Evropske komisije u vezi sa Severnim tokom 2, ističući kako je ovaj projekat u suprotnosti sa ciljevima diverzifikacije Energetske unije i da će povećanjem zavisnosti od ruskog prirodnog gasa samo oslabiti evropsku energetsku bezbednost.

${ }^{45}$ Tim Bogaert, Rock the Pipeline: A Strategic Analysis of the Nord Stream 2 Conundrum, op. cit., p. 32.

${ }^{46}$ Trenutno se projekat suočava sa protivljenjem Evropske komisije i Poljske, kao i američkim sankcijama (Vusala Abbasova, Poland Puts Pressure On Russia Through Nord Stream 2 Gas Pipeline, Caspian News, April 2020, Internet, https:/ / caspiannews.com/ news-detail/poland-puts-pressure-on-russia-through-nord-stream-2-gas-pipeline2020-4-29-39/, 30/4/2020). 
Definisanje kompleksa centriranog oko EU u kontekstu obrazaca (ne)prijateljstva predstavlja sledeći bitan korak analize. Stepen sekuritizacije projekta Severni tok 2 ne treba zanemariti budući da debate oko njegove realizacije i dalje traju, i pored okarakterisanosti ovog projekta kao čisto komercijalnog od strane država pristalica, dok protivljenje Evropske komisije dodatno naglašava tu sekuritizaciju. Mada kompleks i dalje zadržava karakteristike bezbednosne zajednice, jer njegove jedinice (države) ne vide jedna drugu kao pretnju sopstvenoj bezbednosti, treba preispitati mogućnost njegovog vraćanja na nivo bezbednosnog režima usled vidljivog oponiranja druge grupe država i Evropske komisije. Ovakvo stanje stvari ozbiljno je uzdrmalo budućnost integracije evropske energetske politike, te još jednom dolazi do izražaja značaj koji će konačna odluka povodom Severnog toka 2 imati po unutrašnju strukturu kompleksa centriranog oko EU.

Međuregionalna bezbednosna dinamika - ona koja se uspostavlja između kompleksa centriranog oko EU i kompleksa centriranog oko Rusije u domenu energetske bezbednosti - sledeći je nivo analize koji je potrebno rasvetliti u kontekstu ispitivanja uticaja Severnog toka 2, s obzirom na snažnu (među)regionalnu dimenziju koju ovaj projekat ima. Osim toga, zainteresovanost za odnose između EU i Rusije povodom konkretnog pitanja izvire i iz činjenice da Rusija, kako je prethodno pomenuto, predstavlja najvećeg snabdevača EU prirodnim gasom i direktno zainteresovanim akterom za realizaciju Severnog toka 2. Uvid $\mathrm{u}$ istorijat energetskih odnosa između EU i Rusije u kontekstu prirodnog gasa omogućio je sagledavanje glavnih faktora koji su doprineli njihovoj postepenoj politizaciji, a potom i sekuritizaciji. Istorijske, političke, ideološke i druge razlike trasirale su i pravac kojim su se kretali (energetski) odnosi između EU i Rusije u dugogodišnjem periodu. U vezi sa njihovim energetskim odnosima, značajno je napomenuti Ugovor o energetskoj povelji iz 1991. godine koji je bio zamišljen kao instrument za regulisanje zajedničkog energetskog prostora i procese transporta resursa, kroz uvažavanje tržišnih pravila. Međutim, odbijanje ruskog parlamenta da ratifikuje ovaj Ugovor rezultiralo je Sporazumom o partnerstvu i saradnji i bilateralnim energetskim dijalogom. ${ }^{47}$ Ovaj Sporazum nije produžen po isteku inicijalnog desetogodišnjeg perioda i suspendovan je nakon rata u Gruziji 2008. godine i spora oko Ukrajine i Rusije koji je doveo do gasne krize. ${ }^{48}$ Ovakvi događaji istakli su u prvi plan visoku energetsku zavisnost EU od jednog snabdevača gasom i okarakterisali Rusiju kao „nepouzdanog" snabdevača, što je rezultiralo sve glasnijem evropskom

${ }^{47}$ Ruski parlament odbio je ratifikaciju Ugovora o energetskoj povelji smatrajući njen Protokol o tranzitu neprihvatljivim budući da je predviđao da Gazprom otvori svoje gasovode i drugim konkurentima i dobavljačima (Nataliya Esakova, European energy security: analysing the EU-Russia energy security regime in terms of interdependence theory, Springer VS, Heidelberg, 2013, p. 197).

${ }^{48}$ Ibid., p. 199. 
zagovaranju diverzifikacije dobavljača, infrastrukture i ruta snabdevanja. Njihovi energetski odnosi postajali su sve manje komercijalni i sve više obojeni političkom i bezbednosnom pozadinom; regionalna energetska bezbednosna dinamika sve više je dobijala konotaciju bezbednosnog režima, dok pojedine tvrdnje koje dolaze od strane istočnoevropskih zemalja bezbednosnu dinamiku sa Rusijom određuju i kao konfliktnu formaciju. ${ }^{49}$ Aneksija Krima od strane Rusije 2014. godine obnovila je stare bojazni po pitanju bezbednosti snabdevanja EU, a Evropska komisija je sada posedovala alat u vidu pomenutog Trećeg energetskog paketa što je, između ostalog, dovelo do obustavljanja projekta Južni tok..$^{50}$ Naravno, ne treba izgubiti iz vida da potencijalna suspenzija Severnog toka 2 predstavlja pretnju i po rusku energetsku bezbednost, s obzirom na mogući gubitak jednog tržišta u vidu EU iz pozicije države proizvođača gasa (i pored postojeće alternative u vidu Kine i ostatka azijskog tržišta). Ovakvi oprečni interesi komplikuju postojeće energetske odnose na relaciji EU-Rusija, gde se pitanje Severnog toka 2 trenutno nameće kao najznačajnije.

Potencijalna transformacija kompleksa centriranog oko EU u kontekstu Severnog toka 2

Nakon što je izvršena analiza sveukupnog konteksta u kome Severni tok 2 i njegove implikacije po evropsku energetsku bezbednost predstavljaju centralni istraživački problem, potrebno je ukratko skicirati moguće transformacije kompleksa centriranog oko EU povodom konkretnog slučaja. U smislu moguće transformacije jednog regionalnog bezbednosnog kompleksa, TRBK navodi tri varijante: održavanje statusa quo, unutrašnju i spoljnu transformaciju. Prva opcija podrazumeva da nema bitnih promena u esencijalnoj strukturi jednog RBK-a. Unutrašnja transformacija odnosi se na promene esencijalne strukture unutar postojećih granica RBK-a (poput promena anarhične strukture, polariteta ili dominantnih obrazaca (ne)prijateljstva), dok se kod spoljne transformacije promene esencijalne strukture dešavaju izvan utvrđenih granica RBK-a, ili podrazumeva promenu samih granica (poput osvajanja novih teritorija, ujedinjenja sa jedinicama drugih RBK-a, dodavanjem novih država u postojeći RBK ili isključivanje određenih, kao i spajanja dva RBK-a u jedan). ${ }^{51}$

${ }^{49}$ Tim Bogaert, Rock the Pipeline: A Strategic Analysis of the Nord Stream 2 Conundrum, op. cit., p. 37.

${ }^{50} \mathrm{U}$ pitanju je takođe ruski gasovod koji bi zaobišao Ukrajinu i ruski gas preko Balkana dopremao dalje u Evropu. Trenutni Turski tok donekle predstavlja reaktualizaciju nekadašnjeg Južnog toka.

${ }^{51}$ Barry Buzan \& Ole Wæver, Regions and powers: the structure of international security, op.

132 cit., p. 53. 
I dok je održavanje statusa quo malo verovatno s obzirom na pozornost koju je Severni tok 2 podigao među različitim akterima, ne treba izgubiti iz vida mogućnost obustave projekta i nastavak integrativnih procesa u oblasti evropske energetske bezbednosti, koji su bili glavna karakteristika kompleksa pre ovog projekta (iako je i to malo verovatno s obzirom na značajan procenat završenih faza izgradnje).$^{52}$ Drugi scenario - unutrašnja transformacija kompleksa - značio bi sve veću integraciju evropskog energetskog tržišta i uspostavljanje jedinstvenog energetskog nastupa EU. Takva opcija nije malo verovatna s obzirom na sve jaču ulogu Evropske komisije u ovom domenu (a koja, prema teoretičarima Kopenhaške škole studija bezbednosti ima ulogu glavnog aktera $u$ centriranom institucionalnom kompleksu kakav je EU). Kako je prethodno pomenuto, uloga Evropske komisije ključna je za budućnost projekta: ili će ga obustaviti kao što je to bio slučaj sa Južnim tokom i tako jačati Energetsku uniju, ili neće uspeti da ga blokira potvrđujući već etabliranu podelu na zapadne i istočne članice, odnosno zemlje pristalice i oponente projekta Severni tok $2 .^{53}$ Unutrašnja transformacija se svakako može očekivati - ili će to biti jačanje Energetske unije i delovanje EU kao jedinstvenog aktera u oblasti energetske politike, ili vraćanje na stari režim regulisanja energetskih pitanja putem bilateralnih sporazuma. Rečeno terminologijom teorije, unutrašnja transformacija kompleksa centriranog oko EU u svakom slučaju bi se kretala između integracije i (ponovne) fragmentacije. Spoljna transformacija kompleksa, kao treći mogući scenario, takođe je moguća u slučaju realizacije ovog projekta, što bi rezultiralo još dinamičnijom međuregionalnom bezbednosnom dinamikom sa kompleksom centriranim oko Rusije, odnosno približavanjem ova dva kompleksa. Drugim rečima, jačanje takve bezbednosne međuzavisnosti može biti indikator promene spoljnih granica kompleksa centriranog oko EU u pravcu formiranja jačeg superkompleksa sa onim centriranim oko Rusije. Sa druge strane, potpuna obustava projekta bi mogla dovesti do zaoštravanja sveukupnih odnosa sa Rusijom i mogućem prelasku kompleksa sa uspostavljenog bezbednosnog režima u jedan blaži oblik konfliktne formacije. Ipak, mnogi eksperti složni su da bi njegova obustava značila mnogo više za EU negoli za Rusiju budući da Rusija poseduje alternativu za izvoz svog gasa u vidu azijskog tržišta. Alternativa evropskom uvozu pak oličena u vidu dopremanja američkog tečnog gasa, i

${ }^{52}$ Ovde naročito do izražaja dolazi najava Nemačke da neće prihvatiti ruski zahtev za izuzeće Severnog toka 2 od revidirane Uredbe o gasu (Diane Pallardy, Germany to reject derogation for Russia's Nord Stream 2 natural gas pipeline, Indipendent Commodity Intelligence Services, May 2020, Internet, https://www.icis.com/explore/resources / news/2020/05/11/10506304/germany-to-reject-derogation-for-russia-s-nordstream-2-natural-gas-pipeline, 13/5/2020).

${ }^{53}$ Tim Bogaert, Rock the Pipeline: A Strategic Analysis of the Nord Stream 2 Conundrum, op. cit., p. 42. 
dalje je upitna usled visoke cene tankovanja i dopremanja takve vrste gasa na evropski kontinent. U svakom slučaju, Severni tok 2 zaista predstavlja svojevrstan test za evropsku energetsku politiku od čijeg rešenja će zavisiti i budućnost njene integracije. ${ }^{54}$

\section{Zaključne napomene}

Međunarodni karakter debate, $\mathrm{u}$ kombinaciji sa problematizovanim odnosom između evropskih integracionih pokušaja u domenu energetske bezbednosti i bilateralnih energetskih aranžmana, pokazali su kako jedno primarno regionalno bezbednosno pitanje može imati snažan uticaj na nekoliko nivoa analize. Projekat Severnog toka 2, osim što zaista ima snažnu (među)regionalnu dimenziju, igra vrlo bitnu ulogu i na globalnom planu, prvenstveno uzimajući u obzir zainteresovanost Sjedinjenih Američkih Država za njegovu realizaciju. Posmatrajući dosadašnju bezbednosnu dinamiku u domenu energetske bezbednosti na nivou EU, jasno je da je, do sada, bio $u$ pitanju centrirani institucionalni bezbednosni kompleks. Međutim, kontroverzna priroda Severnog toka 2 ozbiljno je poljuljala takvo stanovište, što je rezultiralo podelom država članica na dva suprotna tabora po pitanju podrške njegovoj realizaciji. Dalji integrativni koraci EU u domenu energetske bezbednosti i dalje su upitni, s obzirom na nastojanje pojedinih država članica da sopstvena energetska pitanja rešavaju individualno, oslanjajući se isključivo na bilateralne ugovore sa Rusijom. Ipak, ne treba zanemariti sve glasnije napore Evropske komisije $u$ uspostavljanju jedinstvenog evropskog energetskog nastupa koji sve više dobijaju svoju pravnu i institucionalnu osnovu. Komercijalni interesi svih zainteresovanih strana stoga moraju biti analizirani unutar ukupnog političko-bezbednosnog konteksta koji odlikuje trenutne (energetske) odnose između EU i Rusije.

Trenutni energetski odnosi između EU i Rusije imaju izrazite karakteristike bezbednosne dileme gde svaka uključena strana može ostvariti sopstvenu energetsku bezbednost samo na račun one druge. Ipak, pitanje Severnog toka 2 prevazilazi isključivo energetski domen, budući da će njegovo rešenje zasigurno uticati i na buduću dinamiku sveukupnih odnosa između EU i Rusije, ali i na odnose unutar same Evropske unije, odnosno budućnost evropske energetske integracije.

\section{Bibliografija}

Abbasova, Vusala, Poland Puts Pressure On Russia Through Nord Stream 2 Gas Pipeline, Caspian News, April 2020, Internet, https:/ / caspiannews.com/

${ }^{54}$ Daniela Munteanu \& Ciro Sarno, "South Stream and Nord Stream 2 - Implications for the European Energy Security”, op. cit., p. 86. 
news-detail/poland-puts-pressure-on-russia-through-nord-stream-2gas-pipeline-2020-4-29-39/, 30/4/2020.

Avlichou, Anna, European Energy Union: Continuity or Change?, Universiteit Leiden, Leiden, 2017, pp. 1-27.

Bogaert, Tim, Rock the Pipeline: A Strategic Analysis of the Nord Stream 2 Conundrum, Vrije Universiteit Brussel, Brussel, 2019, pp. 1-49.

"BP Statistical Review of World Energy", British Petroleum, June 2019, pp. $1-62$.

Buzan, Barry, People, states, and fear: The national security problem in international relations, Wheatsheaf Books, Brighton, 1983, pp. 1-262.

Buzan, Barry \& Wæver, Ole, Regions and powers: the structure of international security, Cambridge University Press, Cambridge, 2003, pp. 1-564.

Danas, Tramp potpisao zakon koji sadrži sankcije za gasovod Severni tok dva, Beograd, 2019, Internet, https://www.danas.rs/svet/tramp-potpisaozakon-koji-sadrzi-sankcije-za-gasovod-severni-tok-dva/, 2/4/2020

Deutsche Welle, Germany, EU decry US Nord Stream sanctions, Berlin, 2019, Internet, https://www.dw.com/en/germany-eu-decry-us-nord-streamsanctions/a-51759319, 2/4/2020.

Deutsche Welle, Russia and Ukraine agree to gas transit deal, Berlin, 2019, Internet, https://www.dw.com/en/russia-and-ukraine-agree-to-gastransit-deal/a-51743639, 1/4/2020.

Elliott, Stuart \& Griffin, Rosemary, Nord Stream 2 gas pipeline could be delayed to Q1 2021: Putin, S\&P Global Platts, January 2020, Internet, https:/ / www.spglobal.com/platts/en/market-insights/latest-news/naturalgas/011320-nord-stream-2-gas-pipeline-could-be-delayed-to-q1-2021putin, $17 / 4 / 2020$.

"Energy Strategy of Russia for the Period up to 2030", Ministry of Energy of the Russian Federation, Moscow, 2010, pp. 1-174.

"Energy Union package", COM(2015) 80 final, European Commission, 25 February 2015, pp. 1-21.

"EU imports of energy products - recent developments", Eurostat, May 2019, pp. 1-23.

"EU imports of energy products - recent developments", Eurostat, November 2019, pp. 1-14.

„European Energy Security Strategy“, COM(2014) 330 final, European Commission, 28 May 2014, pp. 1-24.

European Values Center for Security Policy, Public Appeal of security experts from EU member states: 6 reasons Nord Stream 2 will be Germany's strategic mistake for decades to come, Prague, 2018, Internet, https:/ / www.european values.net/nordstream/, 1/4/2020. 
Fischer, Severin, "Nord Stream 2: Trust in Europe", Policy Perspectives, vol. 4, no. 4, March 2016, pp. 1-4.

Gazprom, Nord Stream 2, Moscow, 2019, https://www.gazprom.com/ projects/nord-stream2/,2/4/2020.

Goldthau, Andreas, Assessing Nord Stream 2: regulation, geopolitics $\mathcal{E}$ energy security in the EU, Central Eastern Europe $\mathcal{E}$ the UK, Department of War Studies \& King's Russia Institute, London, 2016, pp. 1-40.

Gotev, Georgi, Nord Stream 2 seeks arbitration in dispute with EU Commission, Euractiv, Brussels, 2019, Internet, https://www.euractiv.com/section/ energy/news/nord-stream-2-seeks-arbitration-in-dispute-with-eucommission/, 5/5/2020.

Honczar, Mychajło, Nord Stream 2 is not just a business. The Baltic is becoming a place of confrontation with NATO, Gazeta Prawna, Warsaw, 2019, Internet, https://serwisy.gazetaprawna.pl/energetyka/artykuly/1422 553,nord-stream-2-nato-obwod-kaliningradzki.html, 1/4/2020.

Jančik, Jan, Nord Stream 2: In accordance with the EU's Energy security strategy?, Faculty of Social Sciences, Prague, 2019, pp. 1-78.

Le Renard, Callie, External Actors and National Preference Formation: European Energy Security Policy \& Relations with Russia, George Mason University, Fairfax, 2013, pp. 1-389.

Lipovac, Milan, Nacionalna bezbednost Republike Srbije u regionalnom bezbednosnom potkompleksu Zapadni Balkan, Fakultet bezbednosti, Beograd, 2016, str. 1-364.

Loskot-Strachota, Agata, Nord Stream 2: policy dilemmas and the future of EU gas market, Norwegian Institute of International Affairs, Oslo, 2016, Internet, https://www.europeangashub.com/wp-content/uploads/ attach_580.pdf, 1/4/2020.

Munteanu, Daniela \& Sarno, Ciro,"South Stream and Nord Stream 2 Implications for the European Energy Security", Analise Europeia, vol. 2, no. 1, 2016, pp. 60-96.

Nataliya, Esakova, European energy security: analysing the EU-Russia energy security regime in terms of interdependence theory, Springer VS, Heidelberg, 2013, pp. 1-280.

"Overview of the secondary EU legislation that falls under the legislative competence of DG ENER and that is currently in force", European Commission, 19 December 2014, pp. 1-24.

Pallardy, Diane, Germany to reject derogation for Russia's Nord Stream 2 natural gas pipeline, Indipendent Commodity Intelligence Services, May 2020, Internet, https:/ / www.icis.com/explore/resources/news/2020/05/11 /10506304/germany-to-reject-derogation-for-russia-s-nord-stream-2natural-gas-pipeline, 13/5/2020. 
Proroković, Dušan, "Geopolitički kontekst energetske bezbednosti", Međunarodni problemi, vol. LXXII, no. 1, 2020, str. 254-273.

"Shared Vision: Common Action: A Stronger Europe. A Global Strategy for the European Union's Foreign and Security Policy", European Union, June 2016, pp. 1-57.

Sinobas, Beatriz \& Samsel van Haasteren, Anna, The Revised Security of Gas Supply Regulation, Central Europe Energy Partners, Brussels, 2016, Internet, https:// www.ceep.be/revised-security-gas-supply-regulation/, 15/4/2020.

Sisu Vicari, Madalina, Nord Stream 2: How A Legal Matter Became Part A Soft Power's Aspect, Vocal Europe, Brussels, June 2017, Internet, https://www.vocaleurope.eu/nord-stream-2-legal-matter-became-partsoft-powers-aspect/,5/5/2020.

Šekarić, Nevena, „Sekuritizacija energetskih odnosa između Evropske unije i Rusije: evropska perspektiva“", Međunarodna politika, vol. LXX, no. 1176, pp. 63-82.

Trapara, Vladimir i Šekarić, Nevena, „Saradnja kao (ne)očekivan efekat energetske bezbednosne dileme: studija slučaja Bugarske, Grčke i Jugoslavije“, Međunarodni problemi, vol. LXXI, no. 2, pp. 215-243.

Yafimava, Katja, Gas Directive amendment: implications for Nord Stream 2, The Oxford Institute for Energy Studies, Oxford, 2019, pp. 1-19. 


\title{
EUROPEAN ENERGY SECURITY: A CASE STUDY OF THE NORD STREAM 2
}

\begin{abstract}
Significant attention has been paid recently to the European Union's efforts towards establishing an integrated energy policy and strengthening of the Energy Union. Consequently, many challenges facing these integration steps are subject to numerous analyses as well. One of the most significant contemporary challenges facing European energy integration is the Nord Stream 2 project, whose implementation leads to increased European energy dependence on Russian natural gas. The main goal of this paper is to analyze the recent trends and impacts related to this pipeline, i.e., to assess its impact on further European Union's integration steps in the field of energy security. Considering the strong regional dimension of this pipeline project, the key theoretical framework that will enable such analysis is the Regional Security Complex Theory, originally developed by the Copenhagen School of Security Studies.

Keywords: European Union, energy security, energy policy, Regional Security Complex Theory, natural gas, Nord Stream 2, pipelines.
\end{abstract}

